\title{
Molluscicidal activities of medicinal plants from eastern China against Oncomelania hupensis, the intermediate host of Schistosoma japonicum
}

\author{
Bang-xing Han, ${ }^{1,2,4}$ Jun Chen, ${ }^{* 1}$ Xun Yang, ${ }^{1}$ Sheng Wang, ${ }^{1}$ Chen-guang Li, ${ }^{1}$ Fang-an Han ${ }^{3}$
}

\author{
${ }^{1}$ School of Pharmacy, Jiangsu University, 301 Xuefu Road, Zhenjiang 212013, Jiangsu, P. R.China, \\ ${ }^{2}$ Research Center of Plant Cell Engineering of Anhui Province, Lu'an, 237012, P. R. China, \\ ${ }^{3}$ Zhenjiang Center for Disease Control And Prevention, Zhenjiang 2120001, P. R. China, \\ ${ }^{4}$ School of Food Science and Technology, Jiangnan University, Wuxi 214122, P. R. China.
}

\begin{abstract}
RESUMO: "Atividades moluscicida de plantas medicinais do leste da China contra Oncomelania hupensis, o hospedeiro intermediário da Schistosoma japonicum." Na busca por produtos naturais que podem ser utilizados para controle da esquistossomose, dezenove extratos de onze plantas medicinais do leste da China foram testados para atividade moluscicida contra o caramujo Oncomelania hupensis. A fração $n$-butanol das folhas frescas de Buddleja lindleyana Fortune, Buddlejaceae, mostrou atividade significativa contra os caracóis. A análise estatística revelou que os valores de CL50 e CL90 para a fração $n$-butanol foram 39,91 mg L-1 e 59,28 mg $\mathrm{L}^{-1}$ por $48 \mathrm{~h}$, respectivamente. Por outro lado, a CL50 para a fração $n$-butanol para peixe-zebra foi $403,24 \mathrm{mg} \mathrm{L}^{-1}$ por $48 \mathrm{~h}$. Portanto, a fração $n$-butanol das folhas frescas de $B$. lindleyana poderá vir a ser um moluscicidas potente e seguro.
\end{abstract}

Unitermos: Buddleia lindleyana, molluscicidal activity, Oncomelania hupensis.

\begin{abstract}
In a search for natural products that could be used to control schistosomiasis, nineteen extracts of eleven medicinal plants from eastern China have been tested for molluscicidal activity against snail Oncomelania hupensis. The $n$-butanol fraction of the fresh leaf from Buddleja lindleyana Fortune, Buddlejaceae, showed significant activity against the snails. Statistical analysis revealed that the LC50 and LC90 values for the $n$-butanol fraction were $39.91 \mathrm{mg} \mathrm{L}^{-1}$ and $59.28 \mathrm{mg}$ $\mathrm{L}^{-1}$ for $48 \mathrm{~h}$, respectively. Otherwise, the LC50 values for the $n$-butanol fraction to zebrafish was $403.24 \mathrm{mg} \mathrm{L}^{-1}$ for $48 \mathrm{~h}$. Therefore, the $n$-butanol fraction of the fresh leaf from $B$. lindleyana may be potent and safe molluscicides.
\end{abstract}

Keywords: Buddleia lindleyana, molluscicidal activity, Oncomelania hupensis.

\section{INTRODUCTION}

Schistosomiasis is a disease caused by infestation of the host by species of the genus Schistosoma (Smith \& Christie, 1989; Lockyer et al., 2003), remains a major public health problem affecting some 200 million people in many parts of the developing world, such as Africa, Asia, and tropical America (Chitsulo et al., 2000; WHO, 2002). Schistosomiasis japonica, is the most common human schistosome, was once prevalent in twelve provinces in the south of China. After 50 years of intensive control activities, schistosomiasis has been eliminated in five provinces (Zhou et al., 2005). Because snail is the intermediate host in which the transformation from miracidium to cercariae occurs, so an important strategy of schistosomiasis controling is to attack and break down the life cycle of
Schistosomiasis japonicum through controlling of the snail. Niclosamide, a chemical molluscicides, is effective measures for the rapid control of the snail, but its use is expensive. Furthermore, side effects reported in literature include the lethal action of niclosamide on non target organisms, such as amphibian and fish (Andrews, et al., 1982). All of these problems push the scientists to focus their attention on plant molluscicides, which are cheaper and locally available alternative to synthetic products used in snail control. Many countries search for safe and lowcost molluscicides by using the naturally occurring plants that can be applied effectively in different habitats, and a large number of plant products with molluscicidal activity have been identified (Adenusi \& Odaibo, 2007, 2008; Ke et al., 2008; Yang et al., 2008; Preetee et al., 2008a, b).

China possesses more than thirty thousands 
plant species, is the third largest genetic diversity of plant species in the world, However less than twelve thousands have been evaluated with respect to their biological characteristics, and only about five hundreds have been subjected to detailed molluscicidal activities against host snail studies (Guo, 1987). Therefore plants still constitute a relatively under-utilised, and potentially very valuable, source for the further discovery of molluscicidal activities against host snail substances. The specific objective of the present study was to examine crude extracts of medicinal plants from the eastern of China for their molluscicidal activities against the snail Oncomelania hupensis. In addition, we will preliminarily discuss its toxicity to non target organisms.

\section{MATERIALS AND METHODS}

\section{Plant materials}

All plant species, shown in Table 1, collected in the Huangshan, Anhui province, China in July 2008, were identified by Prof. De-qun Wang of the Traditional Chinese medicine (TCM) Laboratory, School of Pharmacy, Anhui college of TCM . Voucher specimens are deposited in the Pharmacognosy Laboratory, School of Pharmacy, Jiangsu University.

Plant materials were air dried, then crushed into powder by a pulverizer. The particle size of powder was controlled below 40 mesh. Powdered material $(100 \mathrm{~g})$ was extracted with $95 \%$ ethanol $(1.0 \mathrm{~L})$ and at room temperature $\left(25 \pm 2{ }^{\circ} \mathrm{C}\right)$ for $24 \mathrm{~h}$ and filtered. The residue was extracted twice more in a similar manner. The extract was evaporated under reduced pressure in a rotary evaporator. Ethanolic extracts of tested materials were stored in a freezer at -20 ${ }^{\circ} \mathrm{C}$ until required.

The ethanolic extract of Buddleja lindleyana Fortune, Buddlejaceae, leaf was further extracted by four different solvents one after one: petroleum ether, diethyl ether, ethyl acetate and $n$-butanol (NFBL) saturated by water, and the obtained solutions were evaporated under reduced pressure in a rotary evaporator. Extracts were stored in a freezer at $-20{ }^{\circ} \mathrm{C}$ until required. Each fraction was diluted with an appropriate volume of dechlorinated water in order to provide assay solution as required.

\section{Source of snails}

The snails (Oncomelania hupensis) with relatively uniform in size $(8-10 \mathrm{~mm})$ were collected from the beach of Yangtze River near Zhenjiang in Jiangsu province of China, and acclimatized in the laboratory at room temperature $\left(25 \pm 2{ }^{\circ} \mathrm{C}\right)$ for $24 \mathrm{~h}$.

\section{Molluscicidal activity assay of the extracts}

Molluscicidal activity against $O$. hupensis was performed according to the immersion test method suggested by WHO (1983). For each test, twenty snails were placed in a glass bottle containing $200 \mathrm{~mL}$ of molluscicide solution of the extract. Snails were exposed to the molluscicide solution for 24,48 and $72 \mathrm{~h}$ respectively and kept under normal diurnal lighting. Each test was set in quadruple.

At the set time, the solution in beakers was decanted and the snails were washed with dechlorinated water. The test snails were then left in dechlorinated water and observed for $48 \mathrm{~h}$, and finally the snails were examined to check mortality by mechanical prodding. The ratio of killed snails to tested total snails was expressed as mortality (\%). Finally, to check the snails' resistance, the validity of the test and its relevance, control group of the snails was treated with $1 \mathrm{ppm}$ of Niclosamide. Negative group of the snails was treated with $100 \mathrm{~mL}$ dechlorinated water only.

\section{Screening of molluscicidal active fractions of Buddleja lindleyana}

A $50 \mathrm{mg} \mathrm{L}^{-1}$ of the five fractions of $B$. lindleyana leaf was used to treat the snails. The every twenty snails, as one group, were submerged in beakers containing the test solutions. Snails were exposed to the molluscicide solution for 24, 48 and $72 \mathrm{~h}$ respectively. Each test was set in quadruple.

\section{Concentration dependent between NFBL and climbing of the snails}

Every twenty snails, as one group, were exposed to a concentration series of $70,80,90,100$ and $110 \mathrm{mg} \mathrm{L}^{-1}$ of the NFBL for $48 \mathrm{~h}$. The ratio of climbing snails to tested total snails was expressed as mortality (\%). Each test was set in quadruple.

\section{Glycogen (Gn) and total protein (TPr) assay}

Two concentrations of $103.19,203.38 \mathrm{mg} \mathrm{L}^{-1}$ of the NFBL, $40 \%$ and $80 \%$ of the LC50 value of $24 \mathrm{~h}$ respectively, were used to treat $O$. hupensis snails. The negative group was performed with the dechlorinated water only. Snails were randomly and equally divided into four groups. Every fifty snails, as one group, were submerged in beakers containing the test solutions. After exposure for $24 \mathrm{~h}$, the snails were washed with dechlorinated water, and then left in dechlorinated water, the climbing snails were taken out from the beaker and their soft tissues were dried in oven for $24 \mathrm{~h}$ at $40^{\circ} \mathrm{C}$, and then the dried soft tissues ware grounded into fine powder. Then $2 \mathrm{~mL}$ aqueous of $30 \% \mathrm{KOH}$ was added to the test tube with $10 \mathrm{mg}$ of the powder and incubated in boiling water for $20 \mathrm{~min}$, and then cooled to room temperature. Finally $10 \mathrm{~mL}$ ethanol was added to the tube after cooling. Gn content was 
analyzed by anthrone colorimetric method. $\operatorname{TPr}$ content was detected with KND-04 Kjeldahl nitrogen detection device, and calculated as: $(\operatorname{TPr}) \%=6.25 \times \mathrm{N} \%$.

\section{Zebrafish acute toxicity of NFBL}

Zebrafish were exposed to a concentration series of 100, 200, 300, 400, 500, 600 and $700 \mathrm{mg} \mathrm{L}^{-1}$ for $48 \mathrm{~h}$. Water temperature was $25 \pm 2{ }^{\circ} \mathrm{C}$. Twenty zebrafishs were placed in a glass bottle containing $2000 \mathrm{~mL}$ solution of NFBL. Each test was set in quadruple. The ratio of killed zebrafish to tested total zebrafish was expressed as mortality $(\%)$. No mortalities were observed in the controls.

\section{Statistical analysis}

The molluscicidal activity test data were statistically analyzed by SPSS13.0, and the result was expressed as $\mathrm{M} \pm \mathrm{SD}$. Significantly different was analyzed by One-way ANOVA. The LC50 and LC90 values were calculated by the probit analysis.

\section{RESULTS AND DISCUSSIONS}

\section{Molluscicidal activity of the plant extracts}

The total of nineteen ethanolic extracts of various parts of eleven medicinal plants were assayed for molluscicidal activity and the lethality of 24, 48 and $72 \mathrm{~h}$ were shown in Table 1 . In the above plants extracts, six ethanolic extracts showed medium to strong toxicities towards adult snails within $72 \mathrm{~h}$ exposure at concentrations of $200 \mathrm{mg} \mathrm{L}^{-1}$. However, only the ethanolic extract of $B$. lindleyana leaf showed significant molluscicidal activity within $48 \mathrm{~h}$ exposure. It still showed medium toxicities towards adult snails within $24 \mathrm{~h}$ exposure. The mortality (\%) values was $76.25 \pm 4.79 \%$. Therefore, we focus our attention to the ethanolic extract of $B$. lindleyana leaf.

\section{Screening of molluscicidal active fractions of $B$. lindleyana}

In order to screen the active fractions of $B$. lindleyana, fractions extracted by different solvents of B. lindleyana were assayed for molluscicidal activity. The mortality (\%) values were shown in Figure 1. NFBL exhibited a much higher lethality than other fractions. The NFBL showed $100 \%$ mortality at concentrations of $50 \mathrm{mg}$ $\mathrm{L}^{-1}$ within $72 \mathrm{~h}$.

\section{Molluscicidal activity of NFBL}

For detecting the toxicity of NFBL to snails further, the LC50 and LC90 values for different exposure time were analyzed through probit analysis of the bioassay data (Table 2). NFBL showed significant activity against
O. hupensis. Noteworthy, there was a significant negative correlation between LC50 values and exposure time. When increasing the exposure time, the LC50 value of the NFBL was decreased from $257.00 \mathrm{mg} \mathrm{L}^{-1}(24 \mathrm{~h})$ to 23.08 $\mathrm{mg} \mathrm{L}^{-1}(72 \mathrm{~h})$. It is the same to LC90, when increasing the exposure time, the LC90 value was decreased from 492.85 $\mathrm{mg} \mathrm{L}^{-1}$ (24 h) to $40.47 \mathrm{mg} \mathrm{L}^{-1}$ (72 h).

Simultaneously, there was a significant negative correlation between climbing of the snails and concentration (Figure 2). When increasing the concentration, the climbing of the snails was decreased from $100 \%$ to $0 \%$. The linear regression between climbing of the snails and concentration: $\mathrm{Y}=289-2.7 \times(\mathrm{R}=-0.98459)$.

\section{Gn and TPr content of snails' soft tissues tested}

To preliminarily study the mechanism of NFBL in snail controlling, the Gn and TPr content of snails' soft tissues were analyzed, after the submerging test of snails treated with concentrations less than the LC50 values. The results demonstrated that the Gn content decreased greatly after treatments, ranging from $23.90 \%$ to $34.25 \%$ (Figure 3). The TPr content also decreased after treatments, ranging from $7.74 \%$ to $10.45 \%$ (Figure 4 ). The decreasing rate was parallel to the molluscicidal activity. The stronger the molluscicidal activity, the more decrease Gn content and TPr content.

\section{Zebrafish acute toxicity of NFBL}

In the present study, the zebrafish toxicity assay was used to appraise toxicity to non target aquatic species. The results showed that NEBL was not highly toxic to zebrafish. The LC50 values was $403.24 \mathrm{mg} \mathrm{L}^{-1}$ within 48 $\mathrm{h}$ (Figure 5). It is much higher than that of snail $(39.91 \mathrm{mg}$ $\left.\mathrm{L}^{-1}\right)$. That is to say, NFBL caused $50 \%$ mortality in snails but had no effect on zebrafish at the concentration of 39.31 $\operatorname{mg~L^{-1}}$.

The present results clearly indicated that the leaf of $B$. lindleyana is an important source of botanical molluscicides, and molluscicidal active fractions is NFBL. The toxicity study revealed that the toxic effect is time as well as concentration dependant as evident from negative regression between exposure time. NFBL can decrease the Gn and TPr content in snail's soft tissues suggests that the abnormity of energy metabolism might be a factor for the molluscicidal activity (Wang, et al., 1989).

On the whole, NFBL may be used as potent molluscicides against Oncomelania hupensis. Nevertheless, further studies are required to determine molluscicidal active substance in the NFBL and the mechanism of action of NFBL in snail body. 
Table 1. Plants employed in this study and the activities of ethanolic extracts against Oncomelania hupensis $(n=4)(M \pm S D)$

\begin{tabular}{|c|c|c|c|c|}
\hline \multirow{2}{*}{ Species } & \multirow{2}{*}{ Plant parts extracted } & \multicolumn{3}{|c|}{ mortality $(\%)$ with different submerged periods } \\
\hline & & $24 \mathrm{~h}$ & $48 \mathrm{~h}$ & $72 \mathrm{~h}$ \\
\hline Silybum marianum & fruit & $5.00 \pm 4.08$ & $10.00 \pm 3.54$ & $22.5 .0 \pm 6.46$ \\
\hline Rhinacanthus nasutus & herb & $6.25 \pm 2.5$ & $25.00 \pm 3.54$ & $81.25 \pm 10.31$ \\
\hline Peucedanum praerutorum & root & 0 & $11.25 \pm 5.45$ & $51.25 \pm 8.54$ \\
\hline \multirow[t]{2}{*}{ Buddleia lindleyana } & leaf & $76.25 \pm 4.79$ & $96.25 \pm 4.15$ & 100.00 \\
\hline & branch & 0 & $12.50 \pm 4.33$ & $56.25 \pm 4.79$ \\
\hline \multirow[t]{2}{*}{ Acorus gramineus } & rhizome & $3.75 \pm 4.79$ & $53.75 \pm 4.15$ & $75.00 \pm 4.08$ \\
\hline & leaf & $2.50 \pm 2.89$ & $7.50 \pm 2.50$ & $56.25 \pm 6.29$ \\
\hline \multirow[t]{2}{*}{ Pterocarya stenopt } & leaf & 0 & $26.25 \pm 8.2$ & $50.00 \pm 4.08$ \\
\hline & branch & 0 & $2.50 \pm 2.50$ & $48.75 \pm 2.50$ \\
\hline Clerodendron & branch & $5.00 \pm 4.08$ & $42.50 \pm 5.59$ & $56.25 \pm 4.79$ \\
\hline cyrtophyllum & leaf & 0 & $57.50 \pm 5.59$ & $65.00 \pm 7.07$ \\
\hline \multirow[t]{2}{*}{ Hemerocallis fulva } & leaf & $3.75 \pm 2.50$ & $15.00 \pm 3.54$ & $50.00 \pm 7.07$ \\
\hline & root & 0 & $22.5 \pm 5.59$ & $76.25 \pm 8.54$ \\
\hline \multirow[t]{2}{*}{ Acorus gramineus } & leaf & $10.00 \pm 4.08$ & $28.75 \pm 4.15$ & $75.00 \pm 5.00$ \\
\hline & rhizome & $6.25 \pm 4.79$ & $25.00 \pm 3.54$ & $72.50 \pm 9.57$ \\
\hline Sapium sebiferum & fruit & $3.75 \pm 4.79$ & $8.75 \pm 2.17$ & $55.00 \pm 12.90$ \\
\hline \multirow[t]{3}{*}{ Juglis cathayensis var. formosana } & fruit & 0 & $30.00 \pm 3.54$ & $60.00 \pm 8.17$ \\
\hline & branch & $5.00 \pm 5.77$ & 0 & $52.50 \pm 8.66$ \\
\hline & leaf & $2.50 \pm 2.89$ & $15.00 \pm 3.54$ & $57.50 \pm 6.46$ \\
\hline Dechlorinated water & & 0 & 0 & 0 \\
\hline Niclosamide & & $97.50 \pm 5.00$ & 100.00 & 100.00 \\
\hline
\end{tabular}

Ethanolic extracts tested at a concentration of $200 \mathrm{mg} \mathrm{L}^{-1}$, Niclosamide at a concentration of $1 \mathrm{mg} \mathrm{L}^{-1}$. Fractions tested at a concentration of $50 \mathrm{mg} \mathrm{L}^{-1}$, Niclosamide at a concentration of $1 \mathrm{mg} \mathrm{L}^{-1}$.

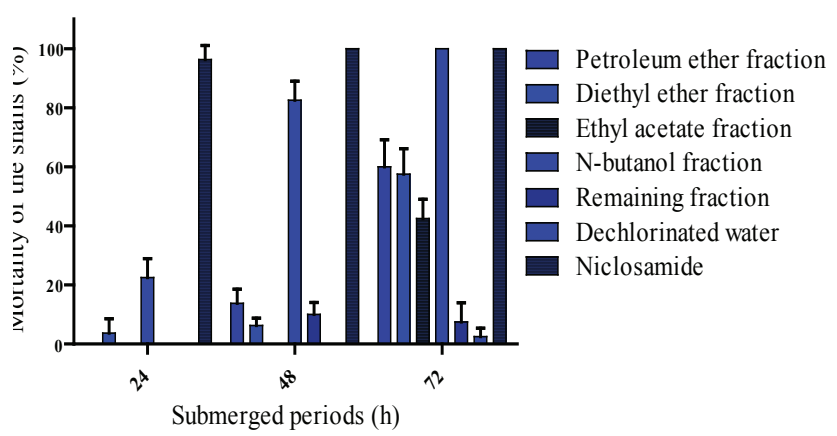

Figure 1. Different fractions of Buddleja lindleyana leaf against Oncomelania hupensis $(\mathrm{n}=4)$

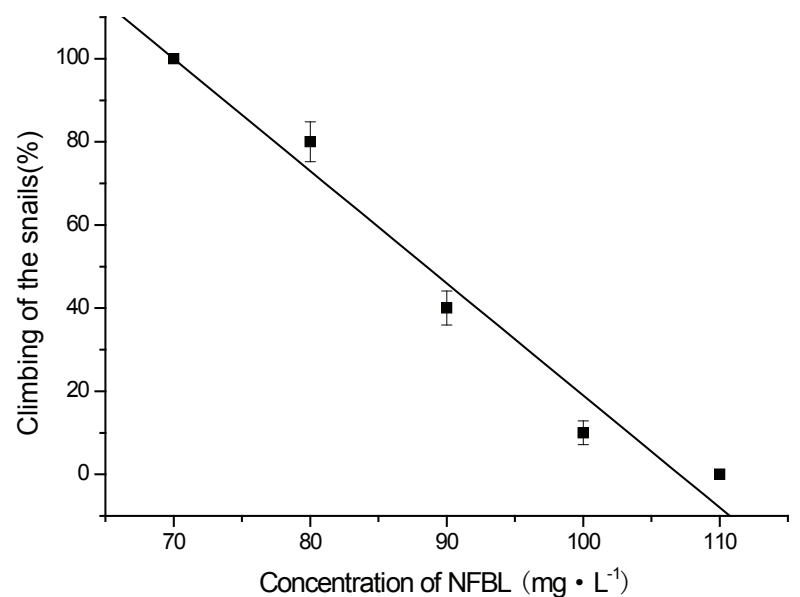

Figure 2. Concentration dependent between NFBL and climbing of the snails $(n=4)$. 


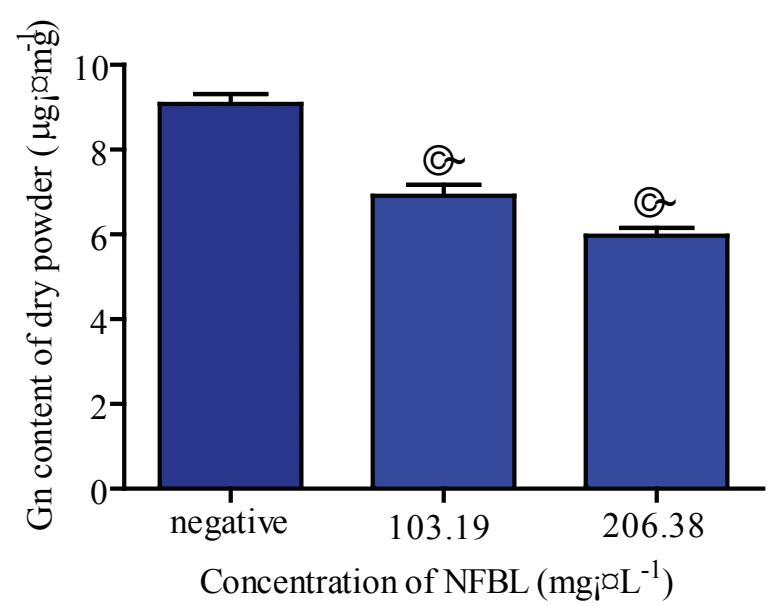

Figure 3. Gn content of soft tissues of snails treated by NFBL $(n=4)$

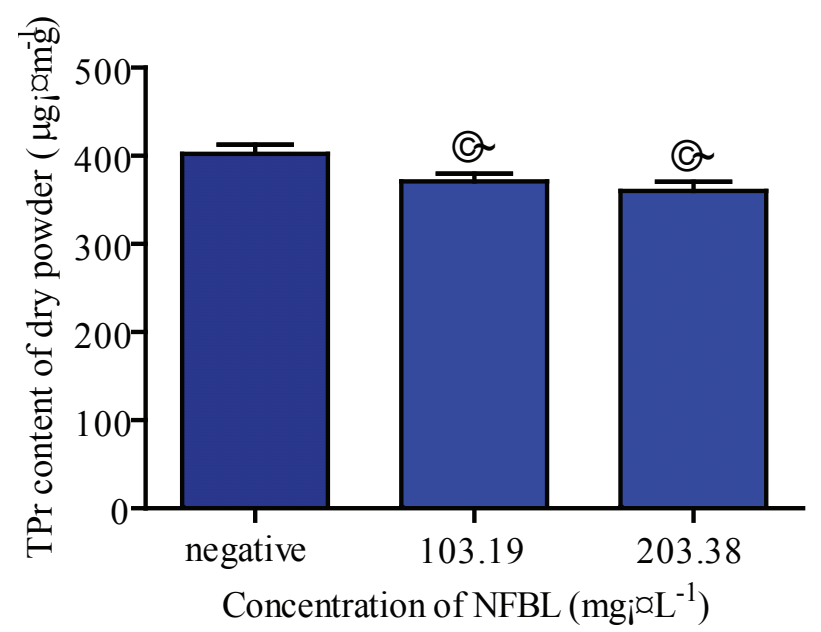

Figure 4. TPr content of soft tissues of snails treated by NFBL $(n=4)$.

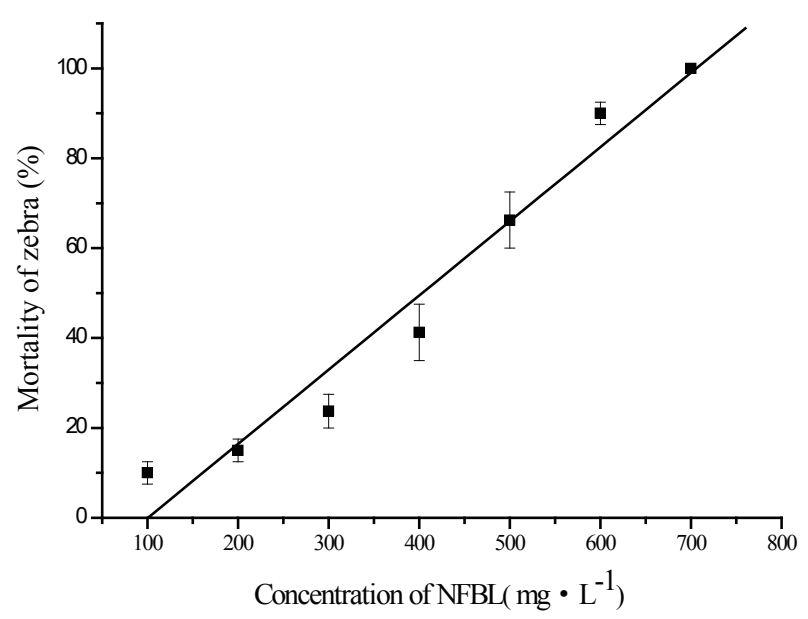

Figure 5. Concentration dependent between NFBL and mortality of zebrafish $(n=4)$.
Table 2. The mortality of snails treated by NFBL $(n=4)$ $(\mathrm{M} \pm \mathrm{SD})$

\begin{tabular}{lccc}
\hline \multirow{2}{*}{$\begin{array}{c}\text { Concentration } \\
\left(\mathrm{mg} \mathrm{L}^{-1}\right)\end{array}$} & \multicolumn{3}{c}{ Mortality $(\%)$ with different time } \\
\cline { 2 - 4 } 15 & $24 \mathrm{~h}$ & $48 \mathrm{~h}$ & $72 \mathrm{~h}$ \\
20 & & $3.75 \pm 2.50$ & $28.33 \pm 4.08$ \\
25 & & $7.50 \pm 9.57$ & $51.67 \pm 9.13$ \\
30 & & $26.25 \pm 9.46$ & $78.33 \pm 4.79$ \\
35 & & $40.00 \pm 4.08$ & $81.67 \pm 8.66$ \\
40 & & $51.25 \pm 4.79$ & $88.33 \pm 4.08$ \\
45 & & $57.50 \pm 6.45$ & $93.30 \pm 4.79$ \\
50 & $13.75 \pm 4.79$ & $75.00 \pm 4.08$ & 100.00 \\
100 & $23.75 \pm 4.79$ & & \\
150 & $33.75 \pm 6.29$ & & \\
200 & $43.75 \pm 12.50$ & & \\
250 & $46.25 \pm 4.79$ & & \\
300 & $56.25 \pm 4.79$ & & \\
LC50 & 257.98 & 39.91 .37 \\
LC90 & 499.37 & 59.28 & \\
\hline
\end{tabular}

Mortality for dechlorinated tap water was $0 \%$, and the mortality for $1 \mathrm{mg} \mathrm{L}^{-1}$ of Niclosamide was $100 \%$ for the test time.

\section{ACKNOWLEDGMENTS}

Authors thank Mr. Long-gen $\mathrm{Li}$ and Baomin Yang (Zhenjiang Center for Disease Control and Prevention, Jiangsu province, China) for providing snail and authentication. We also thank Dr. You-sheng Liang (Jiangsu Institute of Schistosome Diseases, Jiangsu Province, China) for useful suggestions.

\section{REFERENCES}

Adenusi AA, Odaibo AB 2007. Preliminary laboratory assessment of the crude aqueous and ethanolic extracts of Dalbergia sissoo plant parts for molluscicidal, ovicidal and cercaricidal activities. Travel Medicine and Infectious Disease 6: 406.

Adenusi AA, Odaibo AB 2008. Laboratory assessment of molluscicidal activity of crude aqueous and ethanolic extracts of Dalbergia sissoo plant parts against Biomphalaria pfeifferi. Travel Medicine and Infectious Disease 6: 219-227.

Andrews P, Thyssen J, Lorke D 1982. The biology and toxicology of molluscicides, bayluscide. Pharmacology \& Therapeutics 2: 245-295.

Chitsulo L, Engels D, Montresor A, Savioli L 2000. The global status of schistosomiasis and its control. Acta Trop 77: 41-51.

Guo YH 1987. Plant molluscicide studies in the People's Republic of China. In: Mott K E. Plant Molluscicdes. A Willy Medical Publication, p. 289-298.

Lockyer AE, Olson PD, Ostergaard P, Rollinson D, Johnston 
DA, Attwood SW 2003. The phylogeny of the Schistosomatidae based on three genes with emphasis on the interrelationships of Schistosoma Weinland. Parasitology 126: 203-24.

Preetee J, DK Singh 2008a. Molluscicidal activity of Carica papaya and Areca catechu against the freshwater snail Lymnaea acuminate. Veterinary Parasitology 152: 264270.

Preetee, VK Singh, DK Singh 2008b. Enzyme inhibition by molluscicidal component of Areca catechu and Carica papaya in the nervous tissue of vector snail Lymnaea acuminata. Pestic Biochem Phys 92: 164-168.

Ke WS, Yang JL, Meng Z, Ma AN 2008. Evaluation of molluscicidal activities of Arisaema tubers extracts on the snail Oncomelania hupensis. Pestic Biochem Phys 92: 129-132.

Smith JH, Christie JD 1989. The pathology of human Schistosoma haematobium infections. In: Miller MJ, Love EJ. Parasitic diseases: treatment and control. Boca-Raton, FL CRC Press, p. 3-17.

WHO 2002. Prevention and control of schistosomiasis and soiltransmitted helminthiasis. WHO Tech Rep Ser. No. 912

Wang GF, Song GM, Qiu Y 1989. Basic components of snails and the effect of bromide acetamide. Chinese J Zool 24: 4-6.

WHO 1983. Special program for research and training in tropical diseases. TDR: SCH-SWG.

Yang XM, Chen SX, Xia L, Chen J 2008. Molluscicidal activity against Oncomelania hupensis of Ginkgo biloba. Fitoterapia 79: 250-254.

Zhou XN, Wang LY, Chen MG, Wu XH, Jiang QW, Chen XY, Zheng J, Utzinge J 2005. The public health significance and control of schistosomiasis in China - then and now. Acta Trop 96: 97-105. 